\title{
Seed and seedling morphology of Bauhinia scandens $\mathrm{L}$.
}

\section{Morfologia de semente e plântula de Bauhinia scandens L.}

\author{
Tatiane Sanches Jeromini ${ }^{1}$; Givanildo Zildo da Silva2*; Cibele Chalita Martins ${ }^{3 ;}$; \\ Francisco Guilhien Gomes Júnior ${ }^{4}$
}

\section{Highlights}

Morphological description of $B$. scandens aids in its identification in the field.

Majority of high density seeds produce normal seedlings.

Reddish petioles distinguishes $B$. scandens from other species of the same genus.

\begin{abstract}
Bauhinia scandens has potential importance as an ornamental and medicinal plant. Researchers have isolated and identified 1-O-alkylglycerol in the leaves of the B. scandens plant, and established antitumor properties using the Brine Shrimp toxicity test, an internationally accepted bioassay. Although this species has high potential, little is known about the viability of seedling production and the morphology of these plants, particularly in terms of seed characteristics and initial stages of germination. The objective of this study was to characterize the seed morphology, germination, and seedlings of $B$. scandens. Seed water content, weight, and coloration were evaluated. This study also included a description of seed biometrics, external and internal structures, germination, and seedling morphology. Internal seed morphology was evaluated by the anatomical sectioning and X-ray methods. The morphology data obtained were subjected to descriptive statistical analysis and germination data were determined using Cramér's V. B. scandens seeds have a coloration ranging from very dark grayish-red to dark reddish-brown, flat oblong shapes, and rounded bases and apexes with full or slightly undulating margins. Healthy seedlings are produced mainly by seeds with well-formed internal structures. The reddish petiole of the seedling leaves is a taxonomic character for B. scandens identification. The non-domestication and genetic variability of this species reflect on the seed and seedling color and size variation.
\end{abstract}

Key words: Climbing bauhinia. Density. Fabaceae. Internal structure. X-ray.

1 Dra and Lab Analyst Jr. on Basf S.A., Trindade, GO, Brazil. E-mail: tatiane jeromini@hotmail.com

2 Prof. Dr. in Postgraduate Program of Agronomy, Universidade Federal de Jataí, UFJ, Jataí, GO, Brazil. E-mail: givanildozildo@gmail.com

3 Profa Dra on Postgraduate Program of Plant Production, Agronomy, Universidade Estadual Paulista, UNESP, Jaboticabal, SP, Brazil. E-mail: cibele.chalita@unesp.br

4 Prof. Dr. on Postgraduate Program of Phytotechnics, Agronomy, Escola Superior de Agricultura "Luiz de Queiroz", ESALQ/USP, Piracicaba, SP, Brazil. E-mail: francisco1@usp.br

* Author for correspondence

Received: Sept. 22, 2020 - Approved: July 12, 2021 


\section{Resumo}

Bauhinia scandens tem potencial como planta ornamental e importância medicinal. Nas folhas da planta de $B$. scandens, foi relatado pelos pesquisadores, o isolamento e identificação de glicerol 1-O-alquilo, os mesmos estabeleceram a propriedade antitumoral por um bioensaio, aceito internacionalmente denominado teste de toxicidade de Brine Shrimp. Por ser ainda pouco conhecida e com alto potencial exploratório, a viabilidade da produção de mudas e maior conhecimento sobre sua morfologia se faz necessária. Faltam informações sobre as características das sementes e estágios iniciais de germinação. O objetivo deste estudo foi caracterizar o tipo morfológico de sementes, germinação e plântulas de $B$. scandens. Foram avaliados o teor de água, o peso de mil sementes e a coloração das sementes. Este estudo também incluiu a descrição e biometria da semente, estrutura (externa e interna), germinação e morfologia das plântulas. A morfologia interna das sementes foi avaliada por corte anatômico e método de raios-X. Os dados morfológicos obtidos foram submetidos à análise estatística descritiva e os dados de germinação foram testados utilizando Cramér's V. B. scandens apresentam coloração que varia de vermelho acinzentado muito escuro a marrom avermelhado escuro e o tipo de semente é de forma oblonga plana, base e ápice são arredondados e cheios ou margens ligeiramente onduladas. Plãntulas normais são produzidas majoritariamente por sementes com uma estrutura interna bem formada. $\mathrm{O}$ pecíolo avermelhado das folhas da plântula é um caráter taxonômico para identificação de $B$. scandens. A não domesticação e a variabilidade genética desta espécie refletem na variação da cor e tamanho das sementes e plântulas.

Palavras-chave: Bauhinia trepadeira. Densidade. Fabaceae. Estrutura interna. Raios X.

\section{Introduction}

Bauhinia scandens $L$. is originally from Southeast Asia, specifically East India where it is found in tropical and subtropical forests (Bandyopadhyay, Thothathri, \& Sharma, 2005) and considered an important ornamental vine and medicinal plant of the Fabaceae family.

Hazra and Chatterjee (2008) verified the antitumor attributes of the 1-O-alkylglycerol compound extracted from the leaves of this species, suggesting promising uses of the plant in herbal medicines, whereas Hossain, Niloy, Hosen and Islam (2016) found the presence of anti-oxidant activity in $B$. scandens extracts that can be useful in food preservation. Poonsri, Pluempanupat, Chitchirachan, Bullangpoti and Koul (2015) identified insecticidal action using leaf extracts for the control of Plutella xytostella, one of the main pests found in brassicas.

B. scandens has excellent potential for economic exploitation. However, the morphology of seeds and seedlings, as well as the mechanism of seedling production, remain poorly understood. Knowledge of seed and seedling morphology can aid in such areas as taxonomic studies, laboratory germination test interpretations, nursery work, and species ecology research (Ferreira \& Barretto, 2015).

Differences between species, observed mainly in the early stages of growth, included seedling organ coloration, developmental speed, venation, and leaf shape (G. M. C. Silva, Silva, Almeida, Farias, \& Lima, 2003; Borges \& Mendonça, 2009; Khan, Zaki, \& Anis, 2015). 
X-ray analysis can be used to aid morphological descriptions (Jeromini, Martins, Pereira, \& Gomes, 2019; L. A. Silva, Sales, Santos, Martins, Costa, \& Silva, 2017) since it is straight forward, rapid, and accurate in the identification of structures that are imperceptible by conventional techniques (Gomes, 2010).

This method also allows for the observation of seedlings originating from seeds with various malformations, damage, and tissue densities (Leão-Araújo, Gomes, Silva, Peixoto, \& Souza, 2019). Thus, the objective of this study was to morphologically characterize the seeds, germination type, and seedlings of $B$. scandens.

\section{Materials and Methods}

\section{Sample collection and processing}

The fruit of B. scandens was harvested from 10 mother plants in Botucatu, São Paulo, Brazil (22 ${ }^{\circ} 53^{\prime} 09^{\prime \prime} \mathrm{S}$ and 48 ${ }^{\circ} 26^{\prime} 42^{\prime \prime} \mathrm{W}$ ) and sent to the Seed Analysis Laboratory of the Department of Plant Production of UNESP, Jaboticabal, São Paulo. The seeds were extracted from the fruit and homogenized. The water content was determined through the oven method at $105 \pm 3^{\circ} \mathrm{C}$ for $24 \mathrm{~h}$. The results were expressed as a percentage. The weight of 1000 seeds was determined and expressed in grams (Ministério da Agricultura, Pecuária e Abastecimento [MAPA], 2013).

Biometrics and external morphology of the seed

One hundred seeds were randomly selected and length, width, and thickness were measured using a digital caliper. Results were expressed in millimeters (Dutra, Cardoso, Souza, Bandeira, \& Morais, 2016). The seeds were analyzed using a $10 \times$ magnification binocular stereo microscope, gauging the structures with criteria established by Borges and Mendonça (2009) and The Rules for Seed Analysis - MAPA (2009).

The following characteristics were described: color, shape, surface type, base type, and apex type, along with aspects of the hilum, micropyle, and raphe. Seed coloration was verified by comparison with the Munsell color catalog (Munsell, 1976) and results expressed in hue (determined by wavelength), value (brightness or light intensity), and chroma (color saturation).

Internal structure of the seed by the anatomical cutting method

The selected seeds were immersed in distilled water for $24 \mathrm{~h}$ at $25^{\circ} \mathrm{C}$ to soften the tissues and facilitate anatomical cutting, which was performed with a scalpel in the longitudinal direction between the cotyledons and through the embryonic axis. The internal structures were analyzed with the aid of a 10x magnification binocular stereo microscope. The color, form, surface type, cotyledon characteristics, and the embryonic axis were described (Borges \& Mendonça, 2009; MAPA, 2009).

Internal structure of seed by the X-ray method

Five hundred seeds on double-sided tape adhered to a $1 \mathrm{~mm}$ thick transparent acetate film were used. The seeds were positioned $14.3 \mathrm{~cm}$ from the X-ray emission source of the Faxitron X-ray model MX 20 
DC 12 machine to obtain digital radiographs (Abud, Cicero, \& Gomes, 2018).

Radiographic images were analyzed, compared to those obtained by the anatomical cutting method, and separated into five classes according to their internal characteristics, similarly to Jeromini et al. (2019). Seeds of each class were scarified on the opposite side of the hilum with 220-grade sandpaper to overcome dormancy and maintain individuality.

The seeds were placed between two rolled paper towels moistened with $25{ }^{\circ} \mathrm{C}$ water at $2.5 \times$ the weight of the paper towels for 26 days for germination. After which, images of the internal structure of seeds generated by X-rays were compared to determine the percentages of formed seedlings or dead seeds (MAPA, 2013; Abud et al., 2018).

\section{Germination and seedling morphology}

In order for the seeds to overcome dormancy and germinate, seeds were immersed in $40 \mathrm{~mL}$ of $36 \mathrm{~N}$ 95\% sulfuric acid for $60 \mathrm{~min}$, rinsed continuously with water through a sieve for $10 \mathrm{~min}$ until the acid residues were removed, and dried in the shade $\left(25^{\circ} \mathrm{C}\right.$ and $50 \% \mathrm{RH}$ ) on paper towels for $24 \mathrm{~h}$ (Jeromini, Pereira, Silva, \& Martins, 2020).

Sowing was performed with four repetitions of 50 seeds in autoclaved sand moistened with water at $60 \%$ retention capacity (MAPA, 2013), inside plastic boxes (22 $\times 15 \times$ $5 \mathrm{~cm})$. The boxes were kept in a greenhouse (26 $\pm 3{ }^{\circ} \mathrm{C}$ and $60 \% \mathrm{RH}$ ). Measurements and descriptions of the parts of the seedling were performed on samples of 20 normal seedlings obtained at two developmental stages: before true leaf formation (Phase I) and after true leaf expansion (Phase II) (Leonhardt, Bueno, Calil, Busnello, \& Rosa, 2008).
Prior to the formation of true leaves, the length and width of the cotyledonary leaves and the length and diameter of the hypocotyls were measured. After the expansion of the true leaves, the length and width of the first pair of leaves (two open leaflets), and the lengths and diameters of the hypocotyl, epicotyl, and primary root were determined.

The evaluations were made with the aid of a digital caliper and a millimeter ruler. Results were expressed in millimeters (G. M. C. Silva et al., 2003; Leonhardt et al., 2008; Borges \& Mendonça, 2009; Dutra et al., 2016).

A photographic register of the entire germination process and seedling emergence was recorded, as well as the identification of morphological aspects of the seedlings with emphasis on the relevant particularities for the recognition of the species in the field or in a controlled environment, from the emergence of the primary root to that of the second true leaf (Leonhardt et al., 2008).

\section{Statistical analyses}

Data on seed biometrics and seedling structure dimensions were subjected to descriptive statistical analysis to obtain the mean, maximum and minimum dimensions, standard deviation, and coefficient of variation using AgroStat.

The germination percentage data were tested for structure by status using SAS software (v 9.2, SAS, Inc., Cary, NC, USA). PROC FREQ was used to construct contingency tables and analyze all categorical data. The degree of association between variables was analyzed by computing Cramér's V (Sheskin, 2020). Significance was evaluated at $\alpha=0.05$. 


\section{Results and Discussion}

On average, the seeds had $6 \%$ water content and 1000 seeds had a weight of 34.6 g. The shape of the seeds was classified as flat oblong, with a rounded base and apex, and full or slightly undulating margins. The average seed was $6.91 \mathrm{~mm}$ long, $4.34 \mathrm{~mm}$ wide, and $2.29 \mathrm{~mm}$ thick, with a standard deviation of $1.52,0.95$, and 0.19 , respectively (Table 1 ).

This standard deviation data reflects a larger difference between seed length and a smaller difference between seed thickness. The size variation can be considered within the normal range for this genus, as it was also observed for B. monandra (Borges \& Mendonça, 2009) and B. forficata (Dutra et al., 2016).

The seed coat of $B$. scandens showed variable coloration between very dark grayish red; 2.5 YR 2.5/2, and dark reddish-brown; 5 YR 2.5/2 (Munsell, 1976). The surface of the $B$. scandens seed is smooth, polished, and slightly convex (Figure 1A and $\mathrm{B}$ ).

\section{Table 1}

\section{Biometrics of B. scandens seeds}

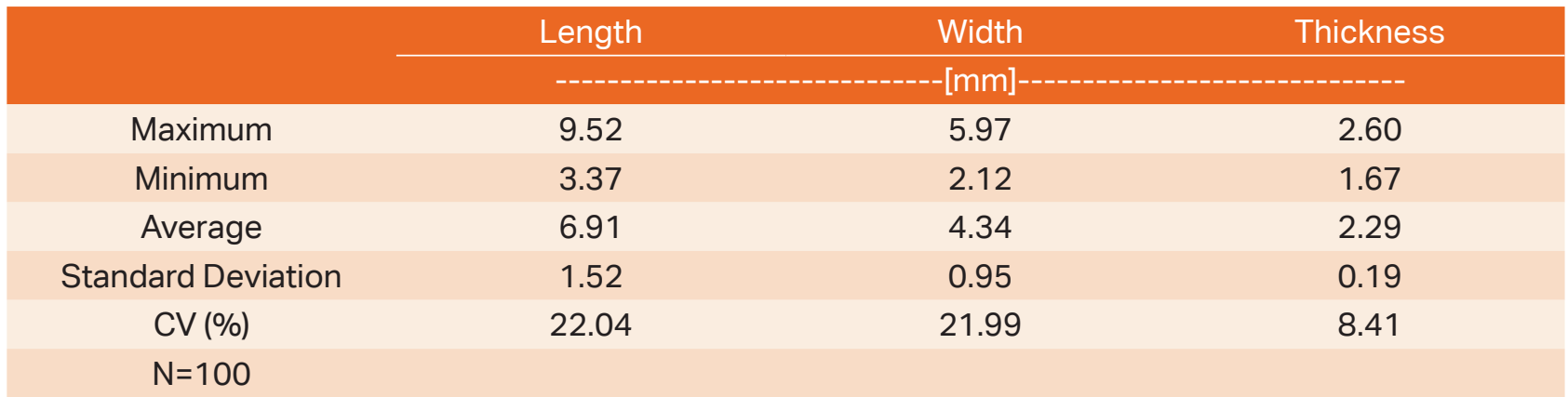

CV- Coefficient of variation.

A

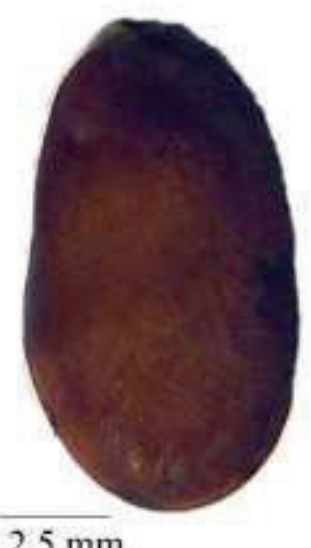

B

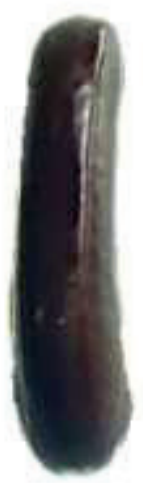

C

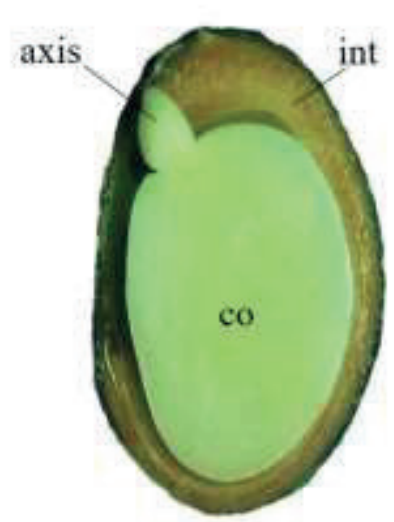

D

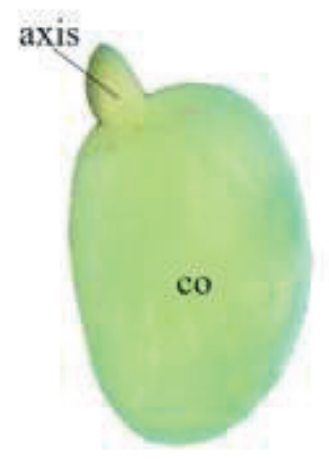

Figure 1. External morphology of the face $(A)$ and lateral side $(B)$ of $B$. scandens seeds and internal structure by anatomical section $(C)$ with visualization of the integument (int), embryonic axis (axis), cotyledon (co) and embryo (D). 
The seed had a small circular micropyle and a V-shaped hilum in the apical region. According to Gunn (1981), this V-shaped hilum is a unique feature of the Bauhinia genus, and external features such as this enabled the clear identification of family, subfamily, and gender of B. monandra (Borges \& Mendonça, 2009).

The hilum was slightly conspicuous and had a very dark grayish red color: 2.5 YR 2.5/2 (Munsell, 1976). The pleurogram, dividing line, micropyle, and lens were absent, and raphe was not visualized in the seeds. The evaluated sample consisted of a mixture of different seed sizes and colors, because undomesticated plants have uneven seed maturation in the pod and high genetic variability among individuals.

Thus, at the time of harvesting, the plot contained heterogeneous seeds in terms of color, size, and density (Mendonça, Martins, Martins, \& Lopes, 2015). For other species of the same family such as Plathymenia foliolosa Benth (Fonseca, Freitas, Mendonça, Souza, \& Abdalla, 2013) and Caesalpinia echinata Lam. (Ferreira \& Barretto, 2015) seed color variability due to different maturity stages was also reported.
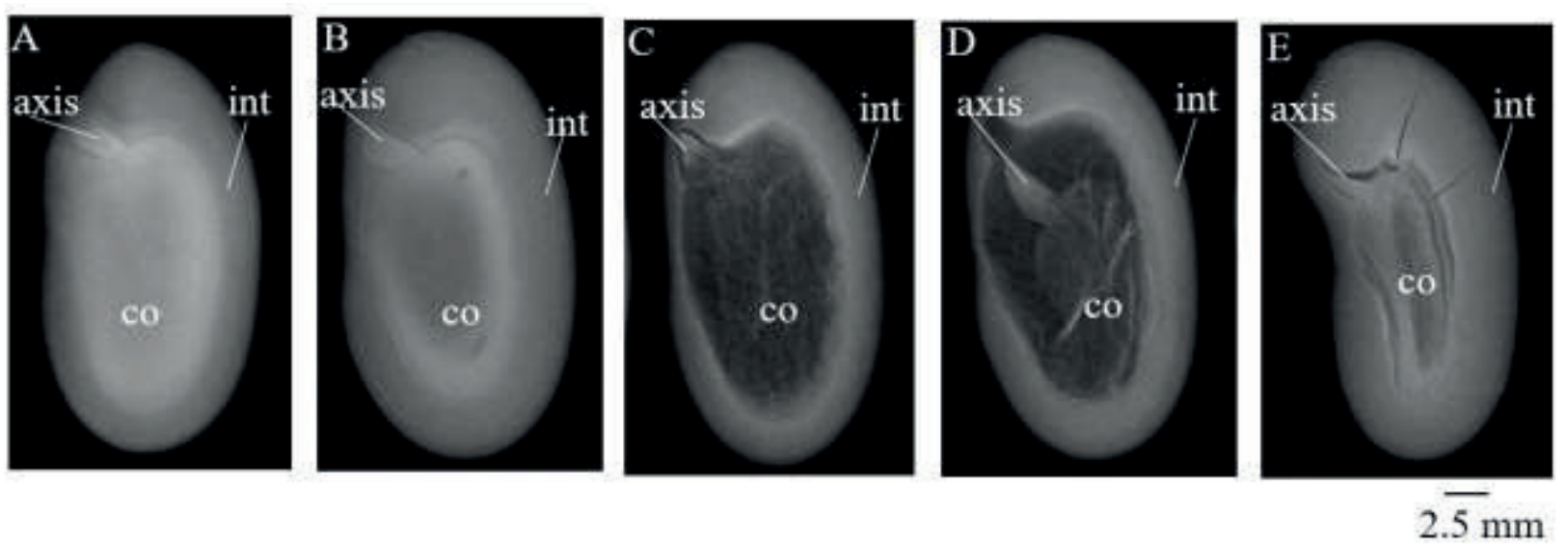

$2 \overline{5} \mathrm{~mm}$ structure of seeds was separated into the following categories (Figure 2): well-formed, with the inner cavity fully filled with high density reserve tissue, characterized by the clear coloration of the cotyledon (Figure 2A); malformed, with the inner cavity filled with low density reserve tissue, identified by the darkened area in the center of the cotyledon (Figure 2B); deteriorated embryo, totally or partially dark, due to low tissue density (Figure $2 \mathrm{C})$; stunted embryo, partially adhered to the external tissues of the seed, so that a dark area of internal cavity in the seed persists (Figure 2D); or cracked tissues (Figure 2E). The percentage of seeds in each category in the sample is presented in Figure 3A. invaginated, and dominant (Figure $1 \mathrm{C}$ and D). The embryonic axis (hypocotyl radicle) had a rudimentary plumule and radicle, with a slight asymmetry and curvature. The two cotyledons were foliate, flat, thick, and spatulate. Cartilaginous consistency was identified with yellowish-white coloration partially covering the embryonic axis, along with a rounded base, entire margin, and blades close to the embryonic axis only.

Based on X-ray analysis, the internal

Figure 2. Radiographic images of $B$. scandens seeds categorized as well-formed (A), malformed (B), deteriorated embryo (C), atrophied embryo (D) and cracked (E). axis = embryonic axis; $\mathrm{co}=$ cotyledon; int = integument. 
X-ray was used to determine the difference between seed tissue densities, with denser and well-formed seeds resulting in brighter images, whereas orifices, damage, or differences in the internal tissues of seeds were identified by a color change and darkened spots (International Seed Testing Association [ISTA], 2009).

Well-formed seeds reflect germination potential and the ability to produce vigorous and normal seedlings. Cramér's V test detected strong levels of association between internal seed morphology and germination capacity $(\mathrm{V}=0.89)$ (Table 2). The germination frequency of well-formed seeds was $91.96 \%$, malformed was $8.84 \%$, and the others seed structures did not produce normal seedlings (Figure 3B).
The results from the germination test are shown in Figure 4. The majority of the wellformed seeds gave rise to normal seedlings, as did some of the malformed seeds (Figure $4 \mathrm{~A})$, whereas most of the malformed seeds and the remaining samples resulted in dead seeds, which displayed microorganisms on their surfaces at the end of the test (Figure 4B, C, D, and E).

The clearest images observed in Figure $4 \mathrm{~A}$ reveal the excellent seed and the accumulation of reserve substances. The high density is reflected in germination potential and the ability to produce a vigorous and normal seedling. Similar results were found for the seeds of Brachiaria brizantha Hochst. Rich (Jeromini et al., 2019), Campomanesia adamantium Camb. (Leão-Araújo et al., 2019), and Brassica oleraceae L. (Abud et al., 2018).

\section{Table 2}

Statistics of structure by status of germination of well-formed, malformed, deteriorated embryo, atrophied embryo, and cracked $B$. scandens seeds evaluated by the X-ray method

\begin{tabular}{|cccc}
\hline Descriptive analysis & DF & Value & Probability \\
\hline Chi-Square & 4 & 404.4272 & $<.0001$ \\
\hline Likelihood Ratio Chi-Square & 4 & 405.0432 & $<.0001$ \\
Mantel-Haenszel Chi-Square & 1 & 214.3793 & $<.0001$ \\
Phi Coefficient & & 0.8994 & 0.6687 \\
Contingency Coefficient & & 0.8994 & \\
Cramer's V & & & \\
\hline
\end{tabular}



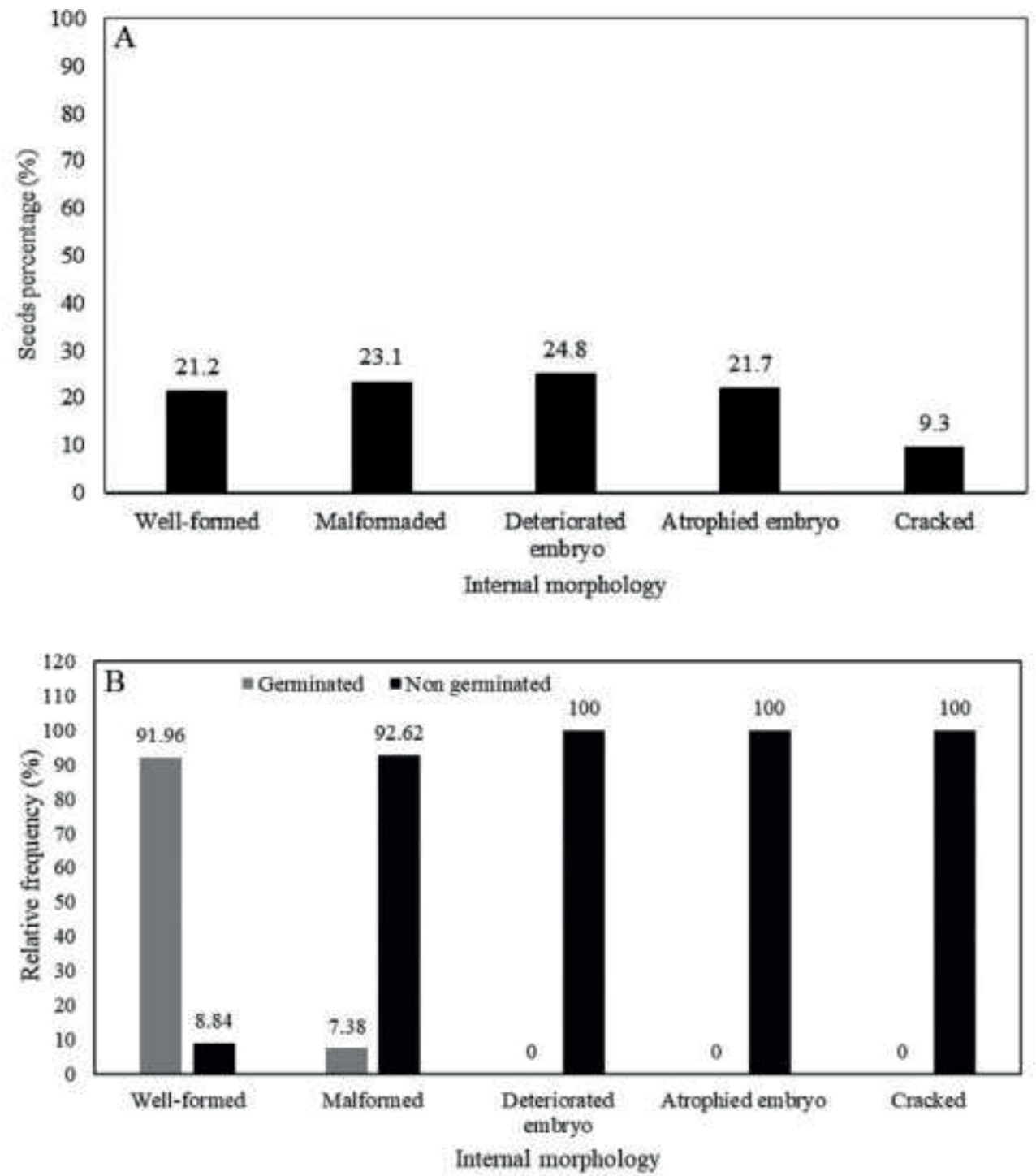

Figure 3. Percentage of seeds (A) and relative frequency of germination (B) of well-formed, malformed, deteriorated embryo, atrophied embryo, and cracked $B$. scandens seeds by X-ray. 

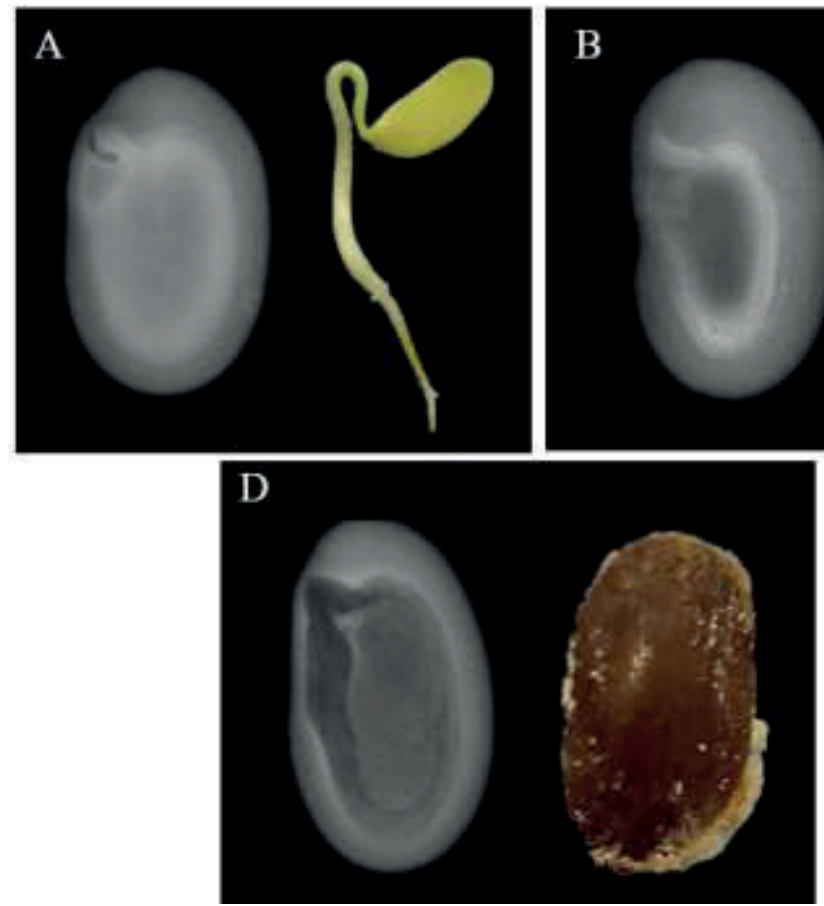
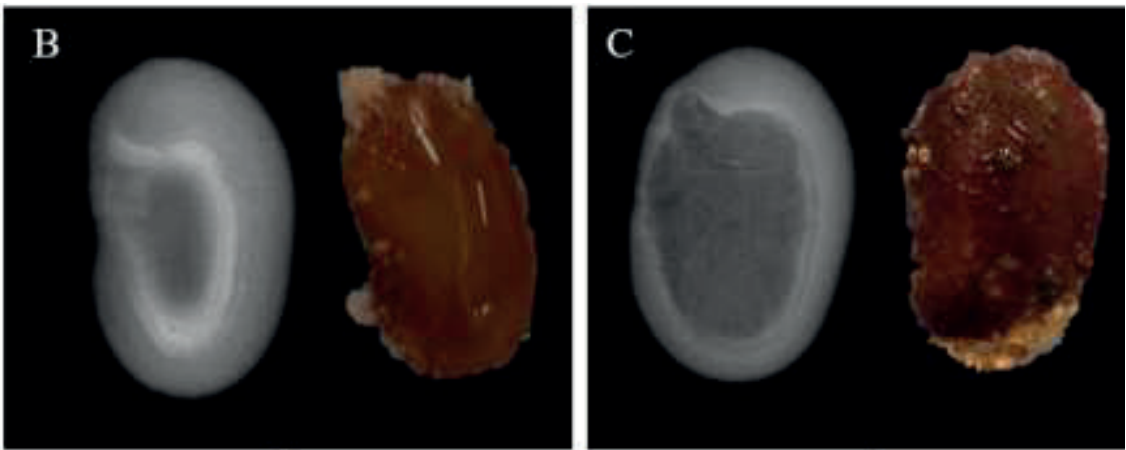

$\mathrm{E}$

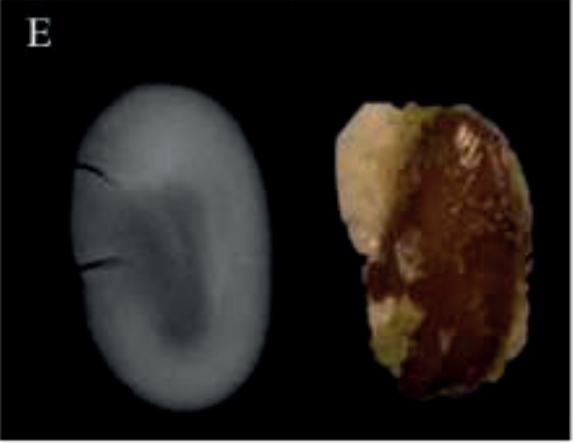

Figure 4. Images obtained in the middle of the germination test by X-ray (left) and at the end of the germination test by binocular stereo microscope (right) show $B$. scandens seeds well-formed $(A)$, malformed (B), with deteriorated embryo (C), with atrophied embryo (D), and cracked (E).

Therefore, the X-ray test can be used to select well-formed seeds associated with high physiological quality expression for seedling production (Severino, Lima, \& Beltrão, 2006). This is a non-destructive method and with low radiation doses in low-density tissues, such as seeds, it does not cause mutations in the cell nucleus (ISTA, 2009).

The germination of $B$. scandens seeds was epigeal and occurred with the development of the embryonic axis between the cotyledon and phanerocotyledon seedling formation, beginning with the rupture of the integument by the primary root in the micropyle area. Seedlings began emerging from the $6^{\text {th }}$ to the $8^{\text {th }}$ day after sowing, and seedlings started to develop on the $9^{\text {th }}$ day after sowing, from the sharp stretching of the hypocotyl and the cotyledons above the ground.

The dimensions of the main structures of the seedling are presented in Table 3: hypocotyl, epicotyl, and cotyledons (Phase I); and first true leaf, shoot, and root (Phase II). In Phase I on the $10^{\text {th }}$ day after sowing, the hypocotyl was $6.69 \mathrm{~mm}$ in length and $1.36 \mathrm{~mm}$ in diameter, both with a standard deviation of 0.059, and the hypocotyl diameter was decreased toward the primary root (Figure 5).

From the $11^{\text {th }}$ day after sowing, the root system displayed a branched, light brown, pivoting root, and the secondary roots were shorter and smaller in diameter than the main root. 
The hypocotyl was described is glabrous, with a green color in the region near the cotyledons, becoming gradually whitish in the portions approaching the ground on the $11^{\text {th }}$ day after sowing. Cotyledons were identified as glabrous, semi-fleshy, and oblong, with rounded bases and apexes, full margins, and actinodrome venation, which were green, as photosynthesizers, and yellowish in the region near the base. In Phase I, cotyledons averaged $12.07 \mathrm{~mm}$ in length and $6.24 \mathrm{~mm}$ in width, with standard deviations of 0.81 and 0.61 , respectively.

\section{Table 3}

Dimensions of the parts of $B$. scandens seedlings

\begin{tabular}{|c|c|c|c|c|c|c|c|c|}
\hline \multirow{3}{*}{ Descriptive analysis } & \multicolumn{6}{|c|}{ Phase I [mm] } & & \\
\hline & \multicolumn{3}{|c|}{ Hipocotyl } & \multicolumn{3}{|c|}{ Epicotyl } & \multicolumn{2}{|c|}{ Cotyledon } \\
\hline & \multicolumn{3}{|c|}{$\mathrm{D}$} & $\mathrm{L}$ & \multicolumn{2}{|c|}{ D } & $\mathrm{L}$ & W \\
\hline Maximum & 6.79 & \multicolumn{2}{|r|}{1.55} & 17.51 & \multicolumn{2}{|c|}{1.42} & 13.85 & 7.43 \\
\hline Minimum & 6.60 & \multicolumn{2}{|r|}{1.36} & 15.36 & \multicolumn{2}{|c|}{0.88} & 10.82 & 5.18 \\
\hline Average & 6.69 & \multicolumn{2}{|r|}{1.45} & 16.43 & \multicolumn{2}{|c|}{1.12} & 12.07 & 6.24 \\
\hline Standard Deviation & 0.059 & \multicolumn{2}{|c|}{0.059} & 0.46 & \multicolumn{2}{|c|}{0.15} & 0.81 & 0.61 \\
\hline CV (\%) & 1.01 & \multicolumn{2}{|c|}{4.06} & 2.84 & \multicolumn{2}{|c|}{13.37} & 6.75 & 9.87 \\
\hline \multicolumn{9}{|l|}{$N=20$} \\
\hline \multicolumn{9}{|c|}{ Phase I [mm] } \\
\hline \multirow{2}{*}{ Descriptive analysis } & \multicolumn{4}{|c|}{ 1st True Leaf } & \multicolumn{2}{|c|}{ Shoot of Plant } & \multicolumn{2}{|c|}{ Root } \\
\hline & $L$ & $\mathrm{~W}$ & $\mathrm{PL}$ & PD & $\mathrm{L}$ & $\mathrm{D}$ & L & $\mathrm{D}$ \\
\hline Maximum & 16.95 & 39.75 & 9.62 & 0,49 & 35.18 & 1.36 & 51.47 & 1.55 \\
\hline Mínimum & 10.30 & 8.10 & 8.24 & 0,35 & 30.87 & 0.83 & 35.06 & 0.54 \\
\hline Average & 13.58 & 16.54 & 9.04 & 0,41 & 33.45 & 1.12 & 43.92 & 1.05 \\
\hline Standard Deviation & 1.68 & 4.53 & 0.47 & 0,04 & 1.55 & 0.14 & 5.41 & 0.40 \\
\hline CV (\%) & 12.42 & 27.43 & 5.29 & 10,41 & 4.63 & 12.91 & 12.32 & 38.53 \\
\hline
\end{tabular}

$\mathrm{CV}=$ coefficient of variation; $\mathrm{L}=$ length; $\mathrm{D}=$ diameter; $\mathrm{W}=$ width; $\mathrm{PL}=$ petiole length, $\mathrm{PD}=$ petiole diameter. 


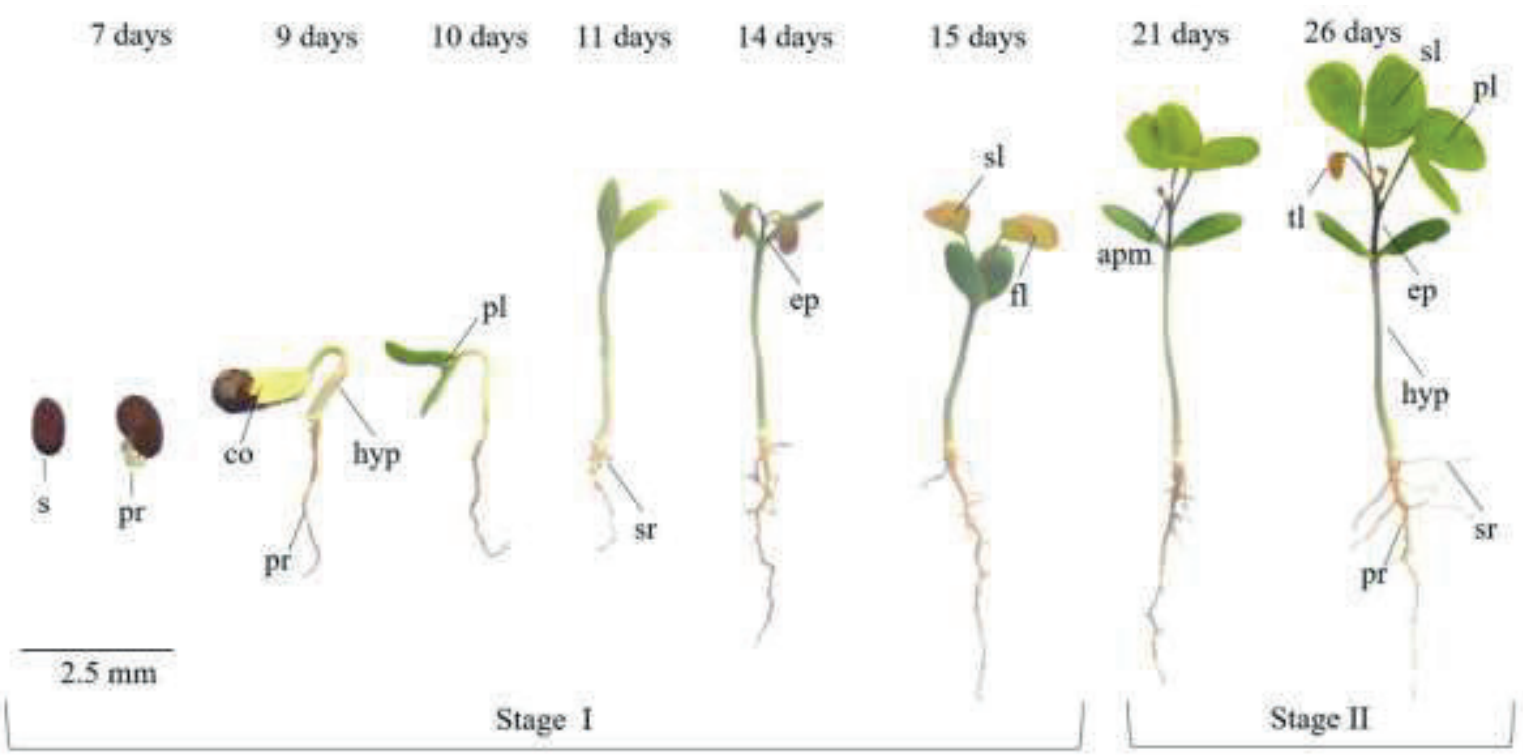

Figure 5. Germination to seedling formation in B. scandens seeds. Stage I = germination stages before the expansion of the first true leaf; Stage II = germination stages after the expansion of the first true leaf; $s=$ seed, $c o=$ cotyledon, hip=hypocotyl, $r p=$ primary root, sdl=seedling, sr=secondary root, ep=epicotyl, pl=primary leaf, sl=secondary leaf, apm=apical meristems, $\mathrm{tl}=$ third leaf.

On the $12^{\text {th }}$ day after sowing, epicotyls started to grow. They were short and reddishbrown, cylindrical, and somewhat hairy. The epicotyl had a mean length of $16.43 \mathrm{~mm}$ and mean diameter of $1.12 \mathrm{~mm}$, with standard deviations of 0.46 and 0.15 , respectively.

The formation of the first true leaf was observed between the $13^{\text {th }}$ and $14^{\text {th }}$ day after sowing, with the gradual development of the epicotyls and formation of new leaves (Figure 5). The $B$. scandens seedling has conduplicate prefoliation, minimal hair, and a reddish color when young, becoming green as it develops. Near the 18th day after sowing, the second leaf formation began, prior to the full development of the first true leaf.

Phase II began on the $21^{\text {st }}$ day after sowing, at which time the first expanded true leaf was observed. The leaf was classified as membranous, and bilobed with a rounded base, entire margins, actinodrome venation, and three veins in each leaflet.

These characters were also described for B. forficata and B. variegata (Lusa \& Bona, 2009). The true leaves had two leaflets next to the petiole, united only by the base, and the leaflets were glabrous in the adaxial face and hairy in the abaxial face.

Therefore, variability among $B$. scandens seedlings was verified in the size of the first leaf. The species B.malabarica and $B$. rufescens had longer Phase II leaf lengths than those observed in B. scandens, 17.00 vs 35.00 $\mathrm{mm}$, respectively (Seetharam \& Kotresha, 1998).

Between the $21^{\text {st }}$ and $23^{\text {rd }}$ day after sowing, the first true leaf had means of $13.58 \mathrm{~mm}$ in length and $16.54 \mathrm{~mm}$ in width, with standard deviations of 1.68 and 4.53, respectively (Table 3). Long, cylindrical, hairy, 
and reddish petioles were found at all stages of leaf development for the true leaves of $B$. scandens (Figure 5).

The petiole color found here had not been described in the literature for other species of the same genus and can thereby be used as a distinguishing characteristic. The petioles of these leaves had means of $9.04 \mathrm{~mm}$ in length and $0.41 \mathrm{~mm}$ in diameter, with standard deviations of 0.47 and 0.04 , respectively (Table 3).

Two straight, greenish stipules were identified at the base of the petiole, along with a globose, green extrafloral nectary between the two stipules for each leaf, differing from other species such as $B$. curvula which possesses a pair of floral nectaries (Rezende, Cardoso, \& Vannucci, 1994).

On the $26^{\text {th }}$ day after sowing, the seedlings presented two expanded leaves with a third beginning to develop. From the development of the second and third leaves, alternate phyllotaxy was identified.

The aerial part of the seedling, from the insertion of the first leaf to the stem at ground level, had a length of $33.45 \mathrm{~mm}$ and a diameter of $1.12 \mathrm{~mm}$, with standard deviations of 1.55 and 0.14 , respectively. The same root diameter was observed in the ground level region of the stem. The pivoting root was $43.92 \mathrm{~mm}$ in length and $1.05 \mathrm{~mm}$ in diameter with standard deviations of 5.41 and 0.40 , respectively (Table 3 ).

B. scandens seedlings showed developmental speed similar to $B$. monandra (Borges \& Mendonça, 2009), with 26 days to final seedling development; however, development exceeded that of $B$. microstachya, whose seedlings required more than two months after sowing to reach the same stage of development (Leonhardt et al., 2008).

\section{Conclusions}

In conclusion, Bauhinia scandens seeds have coloration ranging from very dark grayish-red to dark reddish-brown and flat oblong shapes with a rounded bases and apexes, and full or slightly undulating margins.

Healthy seedlings are produced mainly by seeds with well-formed internal structures.

The reddish petiole of the seedling leaves is a taxonomic character for $B$. scandens identification.

The non-domestication and genetic variability of this species reflect on the seed and seedling color and size variation.

\section{Acknowledgments}

The author(s) thank the Coordenação de Aperfeiçoamento de Pessoal de Nível Superior (CAPES) and the Conselho Nacional de Desenvolvimento Científico e Tecnológico (CNPq; Project number 001) for financial support with the scholarship.

\section{References}

Abud, H. F., Cicero, S. M., \& Gomes, F. G., Jr. (2018). Radiographic images and relationship of the internal morphology and physiological potential of broccoli seeds. Acta Scientiarum-Agronomy, 4O(1), 1-9. doi: 10.4025/actasciagron.v40 i1.34950 
Bandyopadhyay, S., Thothathri, K., \& Sharma, B. D. (2005). The genus Bauhinia (Leguminosae: Caesalpinioideae) in India. Journal of Economic and Taxonomic Botany, 29(4), 763-801. Retrieved from https://www.researchgate.net/ profile/Subir_Bandyopadhyay3publication/277140843_The_genus_Bauhinia_ L_Leguminosae_Caesalpinioideae_in_ India/links/565bec4f08ae4988a7bafd1c. pdf

Borges, F. I., \& Mendonça, M. S. (2009). Mofoanatomia da semente de Bauhinia monandra Kurz. (LeguminosaeCaesalpinioideae). Revista Brasileira de Sementes, 31(4), 168-174. doi: 10.1590/ S0101-31222009000400020

Dutra, F. V., Cardoso, A. D., Souza, B. A. M., Bandeira A. da S., \& Morais, O. M. (2016). Análise biométrica de frutos e sementes de Bauhinia forficata L. Revista Verde de Agroecologia e Desenvolvimento Sustentável, 11(3), 8-12. doi: 10.18378/ rvads.v11i3.4231

Ferreira, R. A., \& Barretto, S. S. B. (2015). Caracterização morfológica de frutos, sementes, plântulas e mudas de paubrasil (Caesalpinia echinata Lamarck). Revista Árvore, 39(3), 505-512. doi: 10. 1590/010 0-67622015000300011

Fonseca, M. D. S., Freitas, T. A. S., Mendonça, A. V. R., Souza, L. S., \& Abdalla, S. D. (2013). Morfometria de sementes e plântulas e verificação da dormência da espécie Plathymenia foliolosa Benth. Comunicata Scientiae, 4(4), 368-376. doi: 10.14295/ cs.v4i4.253

Gomes, F. G., Jr. (2010). Aplicação da análise de imagens para avaliação da morfologia interna de sementes. Informativo Abrates,
20(3), 33-51. Reciperado de http:// www.abrates.org.br/images/stories/ informativos/v20n3/minicurso02.pdf

Gunn, C. R. (1981). Seed topography in the Fabaceae. Seed Science an Tecnology, 9(3), 733-737. Retrieved from https:// agris.fao.org/agris-search/search.do? recordID=XE8280346

Hazra, A. G., \& Chatterjee, P. (2008). A nontoxic antitumour compound from the leaves of Bauhinia scandens characterized as 1- O-alkyl glycerol by gas liquid chromatography and evaluation of its antitumour property by Brine Shrimp bioassay. Industry Crops and Products, 27(1), 39-43. doi: 10.1016/j. indcrop.2007.07.005

Hossain, M. S., Niloy, S. A., Hosen, A., \& Islam, A. U. (2016). Antioxidant activities and HPLC-DAD based phenolic content determination of Bauhinia scandens. British Journal of Pharmaceutical Research, 14(6), 1-9. doi: 10.9734/ BJPR/2016/31817.

International Seed Testing Association (2009). International rules for seed testing. Bassersdorf: ISTA.

Jeromini, T. S., Martins, C. C., Pereira, F. E. C. B., \& Gomes, F. G., Jr. (2019). The use of X-ray to evaluate Brachiaria brizantha seeds quality during seed processing. Revista Ciência Agronômica, 50(3), 439-446. doi: 10.5935/1806-6690.20190052

Jeromini, T. S., Pereira, T. S., Silva, G. Z., \& Martins, C. C. (2020). Overcoming dormancy in Bauhinia scandens seeds. Semina: Ciências Agrárias, 41(4), 11891198. doi: 10.5433/1679-0359.2020v41 n4p1189 
Khan, D. M., Zaki, J., \& Anis, M. (2015). Seedling characteristics of jhinjera (Bauhinia racemosa Lamk.). International Journal of Biology and Biotechnology, 12(1), 143-154. Retrieved from https:// agris.fao.org/agris-search/search.do? recordID=PK2017000129

Leão-Araújo, E. F., Gomes, F. G., Jr., Silva, A. R., Peixoto, N., \& Souza, E. R. B. (2019). Evaluation of the desiccation of Campomanesia adamantium seeds using radiographic analysis and the relation with physiological potential. Agronomy Journal, 111(1), 592-600. doi: 10.2134/ agronj2018.05.0302

Leonhardt, C., Bueno, O. L., Calil, A. C., Busnello, A., \& Rosa, R. (2008). Morfologia e desenvolvimento de plântulas de 29 espécies arbóreas nativas da área da Bacia Hidrográfica do Guaíba, Rio Grande do Sul, Brasil. Iheringia. Série Botânica, 63(1), 5-14. Recuperado de https://isb. emnuvens.com.br/iheringia/article/view/ 156

Lusa, M. G., \& Bona, C. (2009). Análise morfoanatômica comparativa da folha de Bauhinia forficata Link e B. variegata Linn. (Leguminosae, Caesalpinioideae). Acta Botânica Brasilíca, 23(1), 196-211. doi: 10. 1590/S0102-33062009000100022

Mendonça, G. S., Martins, C. C., Martins, D., \& Lopes, M. T. G. (2015). Physical and physiological aspects of seeds of Fimbristylis dicothoma as related to germination and dormancy. Revista Ciência Agronômica, 46(3), 539-545. doi: 10.5935/1806-6690.20150036

Ministério da Agricultura, Pecuária e Abastecimento (2009). Regras para análise de sementes. Brasília: MAPA/ACS.
Ministério da Agricultura, Pecuária e Abastecimento (2013). Instruções para análise de sementes de espécies florestais. Brasília: MAPA/ACS.

Munsell, A. H. (1976). Munsell book of color. Baltimore: Division of koll Margen Corporation.

Poonsri, W., Pluempanupat, W., Chitchirachan, P., Bullangpoti, V., \& Koul, O. (2015). Insecticidal alkanes from Bauhinia scandens var. horsfieldii against Plutella xylostella L. (Lepidoptera: Plutellidae). Industry Crops and Products, 65(1), 170174. doi: 10.1016/j.indcrop.2014.11.040

Rezende, M. H., Cardoso, L. A., \& Vannucci, A. L. (1994). Morfologia e anatomia foliar de Bauhinia curvulha Benth. (LeguminosaeCaesalpinioideae). Acta Botânica Brasílica, 8(1), 19-34. doi: 10.1590/S010233061994000100003

Seetharam, Y. N., \& Kotresha, K. (1998). Foliar venation of some species of Bauhinia spp. and Hardwickia binata Roxb. (Caesalpinioideae). Phytomorphology, 48(1), 51-59. Retrieved from https:// www. researchgate.net/profile/Kotresha_ Katrahalli2/publication/288715787 Foliar_venation_of_some_species_ of_Bauhinia_L_and_Hardwickia binata_roxb_Caesalpinioideae/links/ 5691190908aedOaed8146e0d.pdf

Severino, L. S., Lima, R., \& Beltrão, N. D. M. (2006). Germinação e crescimento inicial de plântulas de pinhão manso em função do peso da semente. Campina Grande: EMBRAPA Algodão-Comunicado Técnico (INFOTECA-E). Retrieved from https://www.infoteca.cnptia.embrapa.br/ bitstream/doc/274845/1/COMTEC309. pdf 
Sheskin, D. J. (2020). Handbook of parametric and nonparametric statistical procedures. New York, NY: CRC Press.

Silva, G. M. C., Silva, H., Almeida, M. V. A., Farias, M. L. C., \& Lima, P. M. (2003). Morfologia do fruto, semente e plântula do Mororó (ou pata de vaca) - Bauhína forficata Linn. Revista de Biologia e Ciências da Terra, 3(2), 1-15. Recuperado de https://www. redalyc.org/pdf/500/50030208.pdf
Silva, L. A., Sales, J. F., Santos, H. O., Martins, J. M., Costa, V. H., \& Silva, F. G. (2017). Physiological performance of cagaita seeds (Eugenia dysenterica DC.) Subjected to drying. Semina: Ciências Agrárias, 38(1), 19-34. doi: 10. 5433/1679-0359.2017v38n1p19 
